\title{
AKTIVITAS ANTIBAKTERI EKSTRAK ETANOL DAUN DAN AMPAS TEH HIJAU (Camellia sinensis L. ) TERHADAP BAKTERI PENYEBAB JERAWAT (Propionibacterium acne DAN Staphylococcus epidermidis ) SECARA DIFUSI AGAR
}

\author{
Herwin, Zulhisda Premeita Sari, Siska Nuryanti
}

Fakultas Farmasi Universitas Muslim Indonesia, Makassar

Email : herwinfarmasi@gmail.com

\begin{abstract}
Acne is one skin problem commonly known as acne vulgaris, that is a state where the skin pores are clogged. Some of the bakteria causing the growth on acne are Propianibacterium acne and Staphylococcus epidermidis. Green tea (Camellia sinensis L.) is one of the plants that can be useful as antibacterial. This study aimed to obtained the antibacterial activity of ethanol extract leaves and sregs of green tea which has the potential to inhibit the growth of acne causing bacteria by the agar diffusion method. The simplisia of green tea leaves and dregs are macerated with ethanol 96\% and obtained the weight of ethanol extract of green tea leaves 34.6 grams. In determination of Minimum Inhibitory Concentration (MIC) ethanol extract of the leaves and the dregs, the MIC value obtained is the same as the two test bacteria on the concentration of $0.1 \%$; whereas, $K B M$ value is on the concentration of $0.4 \%$. The result of the antibacterial activity of ethanol extract of green tea leaves at the largest concentration of $8 \%$ has an inhibitory zone diameter of $18.11 \mathrm{~mm}$ to Propianibacterium acne and $18.05 \mathrm{~mm}$ to Staphylococcus epidermidis. For the antibacterial activity test of ethanol extract the green tea dregs at the largest concentration of $8 \%$ has the largest average inhibitory zone diameter of $17.45 \mathrm{~mm}$ against Propinibacterium acne and $15.68 \mathrm{~mm}$ against Staphylococcus epidermidis.
\end{abstract}

Key words: Green tea, Camellia sinensis L., agar diffusion, antibacterial.

\section{PENDAHULUAN}

Indonesia merupakan negara dengan kekayaan alam yang melimpah, dimana sebagian besar tumbuh-tumbuhan dimanfaatkan oleh nenek moyang kita untuk mengobati berbagai penyakit salah satunya yaitu dalam pengobatan masalah kulit seperti jerawat.
Jerawat merupakan salah satu masalah kulit yang biasa dikenal dengan sebutan acne vulgaris, yaitu suatu keadaan dimana pori-pori kulit tersumbat. Biasanya jerawat atau acne vulgaris mulai timbul pada masa remaja (pubertas). Kondisi tersebut merupakan salah satu masalah yang hampir semua remaja keluhkan baik 
Aktivitas antibakteri ekstrak etanol daun dan ampas teh hijau terhadap bakteri penyebab jerawat Propionibacterium acne dan Staphylococcus epidermidis secara difusi agar

pada wanita maupun pada laki-laki karena dapat mengganggu penampilan. Propionibacterium acne dan Staphylococcus epidermidis merupakan mikroorganisme yang ikut berperan dalam penyebab infeksi jerawat dengan cara memproduksi metabolit yang dapat bereaksi dengan sebum sehingga meningkatkan inflamasi.

Salah satu tanaman yang memiliki potensi sebagai pengobatan alamiah dalam mengatasi jerawat yaitu teh hijau (Camellia sinensis L.). Teh hijau (Camellia sinensis L.) adalah pucuk dan daun muda pada tanaman teh yang diolah tanpa melalui proses fementasi khusus. Tidak diharapkannya proses fermentasi bertujuan untuk mempertahankan kandungan di dalam daun teh segar yang baru dipetik. Bagian daun teh yang mengandung daya antibakteri adalah substansi fenol atau polifenol (katekin, tannin, flavonoid) dan substansi bukan fenol (alkaloid dan flour) yang dapat menghambat dan membunuh bakteri. ${ }^{1,4,5}$

Soetjipto, Martono, dan Setiawan (2012) menyatakan bahwa ampas teh masih memiliki aktivitas antioksidan dan polifenol. ${ }^{2}$ Penelitian lain juga dilakukan oleh Widyaningrum, Badie'ah dan Lestari (2017) yang menyatakan bahwa fraksi etil asetat ampas teh hijau memiliki aktivitas anti jerawat dalam menghambat pertumbuhan Propionibacterium acne dan Staphylococcus epidermidis. ${ }^{3}$ Secara empiris ampas teh dapat digunakan untuk mengobati jerawat dengan cara membalurkan ke wajah lalu didiamkan selama 10-15 menit sebelum dibilas dengan air bersih, serhingga dilakukan penelitian aktivitas antibakteri pada ekstrak daun dan ampas teh hijau (Camellia sinensis L.) bakteri penyebab jerawat menggunakan metode difusi agar.

\section{METODE PENELITIAN}

\section{Alat-alat yang digunakan}

Alat-alat yang digunakan pada penelitian ini adalah gelas ukur $10 \mathrm{~mL}$ (Pyrex), gelas ukur $1000 \mathrm{~mL}$, tabung reaksi (Pyrex), batang pengaduk, api bunsen, ose bulat, cawan petri, toples kaca, incubator, pinset, Erlenmeyer, spoit (1 mL, $5 \mathrm{~mL}, 10 \mathrm{~mL}$ ), autoklaf, oven, spektrometer.

\section{Bahan-bahan yang digunakan}

Bahan yang digunakan yaitu daun teh hijau, ampas daun teh hijau, Medium Nutrien Agar (NA), Medium Nutrient Broth (NB), DMSO, etanol 96\% (pelarut), air steril, air suling, alkohol $70 \%$, Larutan $\mathrm{NaCl}$ fisiologis, $\mathrm{HCl} 0,1 \%$, bakteri uji Propionibakterium acne, Staphylococcus epidermidis. 
Aktivitas antibakteri ekstrak etanol daun dan ampas teh hijau terhadap bakteri penyebab jerawat Propionibacterium acne dan Staphylococcus epidermidis secara difusi agar

PROSEDUR PENELITIAN

Pembuatan Ekstrak Daun dan Ampas Teh Hijau

\section{Ekstraksi Daun Teh Hijau}

Serbuk daun teh hijau (Camellia sinensis L.) ditimbang sebanyak kurang lebih 200 gram, direndam dengan pelarut etanol $96 \%$ dan didiamkan selama 2-3 hari serta ditutup dengan aluminium foil untuk menjaga agar tidak terjadi penguapan dan hasil ekstrak yang diperoleh baik. Rendaman serbuk daun teh hijau diperas menggunakan kertas saring. Prosedur selanjutnya, hasil saringan daun teh hijau diekstrak menggunakan rotavapor pada suhu $60^{\circ} \mathrm{C}$ selama kurang lebih 4 jam yang berguna untuk memisahkan pelarut dengan ekstrak daun teh hijau agar diperoleh ekstrak kental. ${ }^{1}$

\section{Ekstraksi Ampas Teh Hijau}

Ampas daun teh hijau ditimbang sebanyak kurang lebih 200 gram, diekstrak menggunakan etanol $96 \%$ dan dishaker selama 24 jam. Filtrat hasil penyarian disimpan, sedangkan ampas teh dimaserasi lagi sebanyak $3 x$ dengan etanol $96 \%$ selama 1 jam. Semua filtrat yang diperoleh kemudian digabung dan dipekatkan menggunakan rotary evaporator pada suhu $60^{\circ} \mathrm{C} .{ }^{2}$

\section{Uji Skrining Antibakteri Secara} Dilusi Padat

Sebanyak $10 \mathrm{mg}$ ekstrak daun teh hijau (Camellia sinensis L.) dimasukkan ke dalam vial steril dengan 0,2 mL DMSO. Kemudian ditambahkan medium Nutrient Agar (NA) sebanyak 9,8 $\mathrm{mL}$ ke dalam vial lalu dihomogenkan. Setelah itu dituang ke dalam cawan petri steril secara aseptis. Lalu didiamkan hingga memadat dan digoreskan 1 ose mikroba uji Propionibacterium acne diatas medium yang memadat. Dilakukan hal yang sama terhadap bakteri uji Staphylococcus epidermidis. Kemudian diinkubasi pada suhu $37^{\circ} \mathrm{C}$ selama 24 jam. Setelah itu diamati ada atau tidak adanya pertumbuhan bakteri. Diulangi kembali prosedur kerja diatas untuk ekstrak ampas daun teh hijau (Camellia sinensis L.).

\section{Penentuan Konsentrasi Hambat} Minimum

Ekstrak daun dan ampas teh hijau (Camellia sinensis L.) dibuat dengan berbagai variasi konsentrasi $0,1 \%, 0,5 \%, 1 \%, 2 \%$, $4 \%$ dan $8 \%$ dan dimasukkan ke dalam masing-masing tabung reaksi steril, lalu ditambahkan 5 $\mathrm{mL}$ medium NB , setelah itu dimasukkan suspensi bakteri uji, dihomogenkan kemudian diinkubasi pada suhu $37^{\circ} \mathrm{C}$ selama 24 jam.Konsentrasi terendah 
Aktivitas antibakteri ekstrak etanol daun dan ampas teh hijau terhadap bakteri penyebab jerawat Propionibacterium acne dan Staphylococcus epidermidis secara difusi agar

yang menunjukkan larutan jernih Propionibacterium acne dan adalah nilai $\mathrm{KHM}^{8}$

\section{Penentuan Konsentrasi Bunuh \\ Minimum}

Hasil inkubasi pada KHM masing-masing digores pada medium NA dalam cawan petri steril. Kemudian diinkubasi pada suhu $37^{\circ} \mathrm{C}$ selama 24 jam. Konsentrasi terendah dimana tidak terdapat pertumbuhan bakteri menunjukkan nilai KBM. ${ }^{6}$

\section{Uji Aktivitas Antibakteri Secara}

\section{Difusi Agar}

Sebanyak 9,8 $\mathrm{mL}$ medium Nutrient Agar (NA) dimasukkan ke dalam vial steril lalu ditambahkan satu dihomogenkan. Kemudian dituang ke dalam cawan petri steril secara aseptis dan dibiarkan setengah memadat. Lalu diletakkan disc blank pada permukaan medium Nutrient Agar (NA) yang sebelumnya telah direndam dalam varian konsentrasi ekstrak etanol daun dan ampas teh hijau (Camellia sinensis L.).Diulangi perlakuan yang sama dengan menggunakan biakan bakteri Staphylococcus epidermidis. Setelah itu diinkubasi pada suhu $37^{\circ} \mathrm{C}$ salama 24 jam. Dilakukan pengamatan dan pengukuran zona hambat yang terbentuk. ose suspensi biakan bakteri

\section{HASIL PENELITIAN}

Tabel 1. Hasil ekstraksi daun dan ampas teh hijau (Camellia sinensis L.).

\begin{tabular}{ccccc}
\hline Sampel & Jenis Pelarut & $\begin{array}{c}\text { Bobot Sampel } \\
\text { Kering }(\mathbf{g})\end{array}$ & $\begin{array}{c}\text { Volume } \\
\text { Pelarut }(\mathbf{m L})\end{array}$ & $\begin{array}{c}\text { Bobot } \\
\text { Ekstrak }(\mathbf{g})\end{array}$ \\
\hline Daun & Etanol $96 \%$ & 200 & 2000 & 15,86 \\
Ampas & & 28.9 \\
\hline
\end{tabular}

Tabel 2. Hasil skrining antibakteri ekstrak etanol daun dan ampas teh hijau (Camellia sinensis L.) terhadap bakteri Propionibacterium acne dan Staphylococcus epidermidis

\begin{tabular}{ccccc}
\hline \multirow{2}{*}{ Konsentrasi \% } & \multicolumn{2}{c}{ Daun } & \multicolumn{2}{c}{ Ampas } \\
\cline { 2 - 5 } & P. acne & S. epidermidis & P. acne & S. epidermidis \\
\hline 0,1 & + & + & + & +
\end{tabular}

Keterangan

$+\quad=$ Menghambat pertumbuhan mikroba uji 
Aktivitas antibakteri ekstrak etanol daun dan ampas teh hijau terhadap bakteri penyebab jerawat Propionibacterium acne dan Staphylococcus epidermidis secara difusi agar

Tabel 3. Hasil pengujian konsentrasi hambat minimum (KHM) ekstrak etanol daun teh hijau (Camellia sinensis L.) terhadap bakteri Propionibacterium acne dan Staphylococcus epidermidis

\begin{tabular}{cccc}
\hline \multirow{2}{*}{ Kadar \% } & \multicolumn{3}{c}{ Teh Hijau } \\
\cline { 2 - 4 } & P. acne & S. epidermis & Kontrol Media \\
\hline 0,1 & Jernih & Jernih & Jernih \\
0,5 & Keruh & Keruh & Keruh \\
1 & Keruh & Keruh & Keruh \\
2 & Keruh & Keruh & Keruh \\
4 & Keruh & Keruh & Keruh \\
8 & Keruh & Keruh & Keruh \\
\hline
\end{tabular}

Tabel 4. Hasil uji penentuan konsentrasi hambat minimum (KHM) ekstrak etanol ampas teh hijau (Camellia sinensis L.) terhadap bakteri Propionibacterium acne dan Staphylococcus epidermidis

\begin{tabular}{cccc}
\hline \multirow{2}{*}{ Kadar \% } & \multicolumn{3}{c}{ Ampas Teh Hijau } \\
\cline { 2 - 4 } & P. acne & S. epidermis & Kontrol Media \\
\hline 0,1 & Jernih & Jernih & Jernih \\
0,5 & Keruh & Keruh & Keruh \\
1 & Keruh & Keruh & Keruh \\
2 & Keruh & Keruh & Keruh \\
4 & Keruh & Keruh & Keruh \\
8 & Keruh & Keruh & Keruh \\
\hline
\end{tabular}

Tabel 5. Hasil uji penentuan konsentrasi bunuh minimum (KBM) ekstrak etanol daun dan ampas teh hijau (Camellia sinensis L.)

\begin{tabular}{cccccc}
\hline \multirow{2}{*}{$\begin{array}{c}\text { Konstentrasi } \\
\%\end{array}$} & \multicolumn{3}{c}{ Teh Hijau } & \multicolumn{2}{c}{ Ampas Teh Hijau } \\
\cline { 2 - 5 } & P. acne & S. epidermis & \multicolumn{1}{c}{$\boldsymbol{P . ~ a c n e}$} & S. epidermis \\
\hline 0,1 & + & + & + & + & + \\
0,5 & + & + & + & + \\
1 & + & + & + & + \\
2 & + & - & - & - \\
4 & - & - & - & \\
8 & - & & &
\end{tabular}

Tabel 6. Hasil uji aktivitas antibakteri ekstrak etanol daun dan ampas teh hijau (Camellia sinensis L.) terhadap Propionibacterium acne dan Staphylococcus epidermidis secara difusi agar

\begin{tabular}{ccccc}
\hline & \multicolumn{3}{c}{ Diameter Rata-Rata Zona Hambat $(\mathbf{m m})$} \\
\hline \multirow{2}{*}{ Konsentrasi \% } & \multicolumn{2}{c}{ Teh Hijau } & \multicolumn{2}{c}{ Ampas Teh Hijau } \\
\cline { 2 - 5 } & $\boldsymbol{P}$. acne & S. epidermis & $\boldsymbol{P .}$ acne & S. epidermis \\
\hline $\mathbf{0 , 1}$ & 8,74 & 8,05 & 7,74 & 6,88 \\
$\mathbf{0 , 5}$ & 8,98 & 8,32 & 7,83 & 7,20 \\
$\mathbf{1}$ & 10,56 & 9,91 & 10,06 & 9,61 \\
$\mathbf{2}$ & 15,21 & 14,98 & 12,36 & 12,16 \\
$\mathbf{4}$ & 16,40 & 15,86 & 13,58 & 13,57 \\
$\mathbf{8}$ & 18,11 & 18,05 & 17,45 & 15,68 \\
\hline
\end{tabular}


Aktivitas antibakteri ekstrak etanol daun dan ampas teh hijau terhadap bakteri penyebab jerawat Propionibacterium acne dan Staphylococcus epidermidis secara difusi agar

PEMBAHASAN

Penelitian tentang aktivitas antibakteri ekstrak etanol daun dan ampas teh hijau (Camellia sinensis L.) terhadap bakteri Staphylococcus epidermidis dan Propionibacterium acne sebagai alternatif dalam pengobatan jerawat dengan tujuan untuk mengetahui efektivitas antibakteri ekstrak etanol daun dan ampas teh hijau (Camellia sinensis L.) terhadap bakteri penyebab jerawat yaitu Staphylococcus epidermidis dan Propionibacterium acne.

Pengujian pedahuluan aktivitas antibakteri yaitu dengan cara uji skrining, menunjukkan bahwa ekstrak etanol daun dan ampas teh hijau memiliki aktivitas antibakteri terhadap bakteri uji Staphylococcus epidermidis dan Propionibacterium acne. Hasil uji Konsentrasi Hambat Minimum (KHM) secara dilusi cair yang dibuat dalam enam seri konsentrasi yang berbeda untuk mengetahui konsentrasi hambat minimum suatu sampel yang dapat digunakan dalam menghambat pertumbuhan bakteri Propionibacterium acne dan Staphylococcus epidermidis.

Parameter yang digunakan pada penetapan KHM pengujian antibakteri yaitu kekeruhan (ada pertumbuhan bakteri) dan kejernihan (tidak ada pertumbuhan bakteri) yang terlihat setelah diinkubasi selama $1 \times 24$ jam pada suhu $37^{\circ} \mathrm{C}$. Pada konsentrasi $0,1 \%$ ekstrak etanol daun dan ampas teh hijau (Camellia sinensis L.) terhadap bakteri uji Staphylococcus epidermidis dan Propionibacterium acne memiliki kejernihan yang sama dengan kontrol medium, diperoleh nilai KHM pada pengujian ini yaitu 0,1\%.

Pengujian Kadar Bunuh Minimum (KBM) didefinisikan sebagai konsentrasi terendah yang mampu membunuh seluruh pertumbuhan bakteri dan ditetapkan pada konsentrasi yang memberikan zona jernih tanpa pertumbuhan mikroba pada media Agar. ${ }^{7}$ Hasil Kosentrasi Bunuh Minimum menunjukkan bahwa ekstrak etanol daun dan ampas teh hijau diperoleh nilai KBM pada konsentrasi $4 \%$ sudah dapat membunuh bakteri uji Propionibacterium acne dan Staphylococcus epidermidis.

Penguian aktivitas antibakteri secara difusi agar, menurut Davis dan Stout (1971) bahwa aktivitas antibakteri tergolong lemah ketika zona hambatnya kurang dari $5 \mathrm{~mm}$, tergolong sedang dengan zona hambat 5-10 mm, tergolong kuat apabila zona hambat 11-20 $\mathrm{mm}$, dan tergolong sangat kuat apabila zona hambat 20-30 
Aktivitas antibakteri ekstrak etanol daun dan ampas teh hijau terhadap bakteri penyebab jerawat Propionibacterium acne dan Staphylococcus epidermidis secara difusi agar

$\mathrm{mm} .{ }^{8}$ Dari hasil yang diperoleh pada uji

aktivitas antibakteri secara difusi agar, konsentrasi $0,1 \%-1 \%$ untuk ekstrak etanol daun dan ampas teh hijau termasuk kategori sedang dan pada konsentrasi $2 \%-\%$ termasuk kategori kuat. Hasil pengujian aktivitas antibakteri ekstrak etanol daun dan ampas teh hijau secara difusi agar terhadap bakteri Propionibacterium acne dan Staphylococcusc epidermidis dengan enam seri konsentrasi yaitu $0,1 \%, 0,5 \%, 1 \%, 2 \%$, $4 \%$ dan $8 \%$, diperoleh diameter zona hambat terhadap Propionibacterium acne yaitu pada kosentrasi $8 \%$ sebesar $18.11 \mathrm{~mm}$.

\section{KESIMPULAN}

Nilai kosentrasi hambat minimum ekstrak etanol daun dan ampas teh hijau terhadap Propionibacterium acne dan Staphylococcus epidermidis yaitu $0,1 \%$ dan nilai kosentrasi bunuh minimum ekstrak etanol daun dan ampas teh hijau terhadap Propionibacterium acne dan Staphylococcus epidermidis yaitu $4 \%$. Diameter zona hambat terbesar ekstrak etanol daun dan ampas teh hijau yaitu pada konsentrasi $8 \%$ dengan diameter zona hambat ratarata teh hijau yaitu $18,11 \mathrm{~mm}$ terhadap Propionibacterium acne dan 18,05 mm terhadap Staphylococcus epidermidis sedangkan diameter zona hambat rata- rata ampas teh hijau terhadap Propionibacterium acne yaitu 17,45 $\mathrm{mm}$ dan 15,68 $\mathrm{mm}$ terhadap Staphylococcus epidermidis.

\section{DAFTAR PUSTAKA}

1. Saraswati FN. Uji Aktivitas Antibakteri Ekstrak Etanol 96\% Limbah Kulit Pisang Kepok Kuning (Musa balbisiana) Terhadap Bakteri Penyebab Jerawat (Staphylococcus epidermidis, Staphylococcus aureus, dan Propionibacterium acne) (Skripsi).Jakarta: Fakultas Kedokteran dan IImu Kesehatan, Universitas Islam Negeri Syarif Hidayatullah, 2015.

2. Soetjipto $\mathrm{H}$, Martono $\mathrm{Y}$ \& Setiawan TH. Potensi Pemanfaatan Ekstrak Ampas Teh Hijau Fraksi Etil Asetat Sebagai Agensia Antibakteri. Seminar Nasional Kimia dan Pendidikan Kimia IV. 2012.pp. 388.

3. Widyaningrum N, Badie'ah, Lestari S. Antibacterial Activity of The Dregs of Green Tea Leaves (Camellia Sinensis L) on Staphylococcus epidermidis as Causes of Acne. Journal of Science Science Education. 2017;1(2):3.

4. Widyaningrum N. Epigallocatechin3-Gallate (EGCG) Pada Daun Teh Hijau Sebagai Anti Jerawat. Majalah Farmasi dan Farmakologi. 2013;17(3):96.

5. Widyaningrum $N$, Fudholi A, Sudarsono \& Setyowati EP. Stability of Epigallocatechin Gallate (EGCG) from Green Tea (Camellia sinensis) and its Antibacterial Activity against Staphylococcus epidermidis ATCC 35984 and Propionibacterium acnes 
Aktivitas antibakteri ekstrak etanol daun dan ampas teh hijau terhadap bakteri penyebab jerawat Propionibacterium acne dan Staphylococcus epidermidis secara difusi agar

ATCC 6919. Asian J. Biol. Sci. 20158(2).

6. Mile FA. Aktivitas Antibakteri Ekstrak Etanol Batang Phytocrene macrophylla Blume Dengan Metode Difusi Agar (Skripsi). Makassar: Fakultas Farmasi, Universitas Muslim Indonesia, 2016.
7. Efendi YN \& Hertiani T. Potensi Antimikroba Ekstrak Etanol Sarang Semut (Myrmecodia tuberosa Jack.)Terhadap Candida albicans, Escherichia coli dan Staphylococcus aureus.Traditional Medicine Journal. 2013:18(1):56.

8. Davis \& Stout. Disc Plate Method of Microbiological Antibiotic Essay. Journal of Microbiology. 1971;22(4). 